\title{
Local characteristics of the standing genetic diversity of European beech with high within-region differentiation at the eastern part of the range ${ }^{1}$
}

\author{
M. Höhn, E. Major, A. Avdagić, K. Bielak, M. Bosela, L. Coll, L. Dinca, F. Giammarchi, A. Ibrahimspahić, \\ M. Mataruga, M. Pach, E. Uhl, T. Zlatanov, K. Cseke, Zs. Kovács, B. Palla, M. Ladányi, and B. Heinze
}

\begin{abstract}
Developing "climate smart forestry" (CSF) indicators in mountain forest regions requires collection and evaluation of local data and their attributes. Genetic resources are listed among the core indicators for forest biological diversity. This study is a report on the evaluation of the standing genetic diversity within and across 12 pure beech stands (Fagus sylvatica L.) established within the CLIMO (CLImate Smart Forestry in MOuntain Regions) project, using nuclear microsatellite markers. The sampling sites were set along the species' distribution range, including the Balkan region and extending towards the Iberian Peninsula. Cores or leaves from 20 to 23 old, mature trees per plot were sampled for DNA analysis. Genetic diversity indices were high across the range $\left(H_{\mathrm{E}}=0.74-0.81\right)$ with the highest in the Bosnian Mountains. Genetic divergence increased significantly with the geographical distance (Mantel test: $r=0.81, p<0.001$ ). Most of the stands exhibited an excess of heterozygotes, with the highest value at the Hungarian site $\left(H_{\mathrm{O}} / \mathrm{H}_{\mathrm{E}}=1.177\right)$, where beech persists close to the eastern xeric limit of the species' distribution. STRUCTURE revealed within-region differentiation in the Balkan Peninsula, where the Bulgarian stand was the most outstanding. The genetic parameters of each stand could be assessed as a resource for CSF indicators interpreted especially at the local level.
\end{abstract}

Key words: Fagus sylvatica, heterozygosity, F statistics, geographical groups, environmental variables.

Résumé : Le développement d'indicateurs de foresterie intelligente face au climat (FIFC) dans les régions forestières montagneuses exige la collecte et l'évaluation de données locales et de leurs attributs. Les ressources génétiques sont considérées comme des indicateurs de base pour la diversité biologique de la forêt. Cette étude est un rapport sur l'évaluation de la diversité génétique actuelle dans et parmi 12 peuplements purs de hêtre commun (Fagus sylvatica L.) établis dans le cadre du projet CLIMO (CLIMO ("CLImate Smart Forestry in MOuntain Regions») à l'aide de marqueurs microsatellites nucléaires. Les sites d'échantillonnage ont été établis le long de l'aire de répartition de l'espèce, incluant la région des Balkans et se prolongeant vers la péninsule ibérique. Des carottes ou des feuilles prélevées sur 20 á 23 vieux arbres matures par place échantillon ont été échantillonnées pour l'analyse de l'ADN. Les indices de diversité génétique étaient élevés $\left(H_{\mathrm{E}}=0,74-0,81\right)$ à travers l'aire de répartition; les plus élevés ont été observés dans les montagnes de Bosnie. La divergence génétique augmentait significativement avec la distance géographique (test de Mantel $: r=0,81, p<0,001$ ). La plupart des peuplements avaient un excès d'hétérozygotes : le site hongrois, où le hêtre persiste près de la limite xérique orientale de l'aire de

Received 15 September 2020. Accepted 2 March 2021.

M. Höhn, E. Major, Zs. Kovács, and B. Palla. Department of Botany, Institute of Agronomy, Hungarian University of Agriculture and Life Sciences, Ménesi Street 44, H-1118 Budapest, Hungary.

A. Avdagić and A. Ibrahimspahić. Faculty of Forestry, University of Sarajevo, Zagrebačka 20, 71000 Sarajevo, Bosnia and Herzegovina.

K. Bielak. Department of Silviculture, Institute of Forest Sciences, Warsaw University of Life Sciences, Nowoursynowska 159/34, 02776 Warsaw, Poland.

M. Bosela. Department of Forest Resource Planning and Informatics, Technical University in Zvolen, Masaryka 24, 96001 Zvolen, Slovakia.

L. Coll. Department of Agricultural and Forest Engineering \& Joint Research Unit CTFC-AGROTECNIO-CERCA, Universitat de Lleida, 25198 Lleida, Spain.

L. Dinca. Department of Ecology, National Research and Development Institute in Forestry "Marin Dracea”, Voluntari, Romania.

F. Giammarchi. Faculty of Science and Technology, Free University of Bolzano-Bozen, Piazza Università 1, 39100 Bolzano, Italy.

M. Mataruga. Faculty of Forestry, University of Banja Luka, Stepe Stepanovica 75a, 78000 Banja Luka, Bosnia and Herzegovina.

M. Pach. Department of Ecology and Silviculture, Faculty of Forestry, University of Agriculture in Krakow, Al. 29-listopada 46, 31425 Krakow, Poland.

E. Uhl. TUM School of Life Sciences, Technical University of Munich, Hans-Carl-von-Carlowitz-Platz 1, D-85354 Freising, Germany.

T. Zlatanov. Institute of Biodiversity and Ecosystem Research, Bulgarian Academy of Sciences, 2 Gagarin Street, 1113 Sofia, Bulgaria.

K. Cseke. Department of Tree Breeding, ERTI Forest Research Institute, Várkerület 30/A, H-9600 Sárvár, Hungary.

M. Ladányi. Department of Applied Statistics, Institute of Mathematics and Basic Science, Hungarian University of Agriculture and Life Sciences, Villányi Street 29-43, H-1118 Budapest, Hungary.

B. Heinze.* Austrian Federal Research Centre for Forests (BFW), Seckendorff-Gudent Weg 8, 1130 Vienna, Austria.

Corresponding author: M. Höhn (email: Hohn.Maria@uni-mate.hu).

*Berthold Heinze served as an Associate Editor at the time of manuscript review and acceptance; peer review and editorial decisions regarding this manuscript were handled by Milica Kasanin-Grubin.

${ }^{1}$ This Article is part of a collection of papers presented at the CLImate-Smart Forestry in MOuntain Regions (CLIMO) workshop held in Stará Lesná, Slovakia, 9-11 September 2019.

() 2021 The Author(s). This work is licensed under a Creative Commons Attribution 4.0 International License (CC BY 4.0), which permits unrestricted use, distribution, and reproduction in any medium, provided the original author(s) and source are credited. 
répartition de l'espèce, avait la valeur la plus élevée $\left(H_{\mathrm{O}} / H_{\mathrm{E}}=1,177\right)$. STRUCTURE a révélé une différenciation au sein de la région dans la péninsule des Balkans, où un peuplement bulgare était le plus remarquable. Les paramètres génétiques de chaque peuplement pouvaient être évalués en tant ressource pour les indicateurs de FIFC interprétés particulièrement à l'échelle locale. [Traduit par la Rédaction]

Mots-clés : Fagus sylvatica, hétérozygotie, statistique F, groupes géographiques, variables environnementales.

\section{Introduction}

Forests play an important role in the mitigation of the effects of climate change. Therefore, climate smart forestry (CSF) may significantly invigorate the positive effects of forests and provide further benefits for sustainable ecosystems (Nabuurs et al. 2018). Regional environmental conditions as well as traditional forest management may strongly differ; however, the overall integrated survey and development of indicators creates good possibilities for revealing the synergies, evaluating local aspects, and finally building up local strategies for sustaining resilient forests. Providing a guiding framework for future research, practice, and policy, a comprehensive and shared definition of CSF and of the indicators of the "climate-smartness" have been recently suggested by the EU COST CLIMO (CLImate Smart Forestry in MOuntain Regions) action (http://climo.unimol.it/). A total of 29 indicators for assessing CSF were selected; they refer to adaptation and mitigation strategies, considering also the benefits that forests provide to the society. According to Bowditch et al. (2020), CSF “. . . is a sustainable adaptive forest management and governance to protect and enhance the potential of forests to adapt to and mitigate climate change. The aim is to sustain ecosystem integrity and functions and to ensure the continuous delivery of ecosystem goods and services while minimising the impact of climate-induced changes on wellbeing and nature's contribution to people". Genetic resources are listed as part of the core group of CSF indicators for "forest biological diversity" (Bowditch et al. 2020); these indicators contribute in the evaluation of forest health and vitality, which may strengthen adaptation and mitigation measures and are crucial for protecting and maintaining other forest functions and services. Regarding the genetic constitution of species and their populations, studies have revealed that a high level of "standing genetic diversity" preserved in species and their populations is a principal prerequisite to face environmental changes and provide the ability for the populations to survive heterogeneous climatic and spatial conditions (Vornam et al. 2004; De Carvalho et al. 2010). While adaptation induced by selection and fixation of new mutations takes comparatively long in species having a long life span, like forest trees, standing variation most probably has already passed through "selective filters" and might have been formerly tested during selection in past environments (Barrett and Schluter 2008). Moreover, the precondition of fast and effective genetic adaptation in all species is a sufficiently large genetic diversity (Mátyás and Kramer 2016). Genetic characteristics of living tree populations depend on the historical demography of populations, ancestral dynamics of the effective population size, expansions, declines or divergence at geological time scale (Hewitt 2004).

Evolution and historical demography of European forest tree species have already been deeply studied by use of molecular markers, revealing different patterns of variation. Range wide studies were performed on European beech (Fagus sylvatica L.), a keystone tree species of the mountain forest communities, using isozymes (Belletti and Lanteri 1996; Comps et al. 2001; Gömöry et al. 2003) and chloroplast and nuclear DNA markers (Demesure et al. 1996; Vornam et al. 2004; Buiteveld et al. 2007). A combination of palaeobotanical and genetic data have revealed that beech sustained in multiple refugia during the last glacial period, among which the Central European refugium was separated from that of the Mediterranean. Along the mountain chains, the expansion of some of the beech populations was facilitated but not all refugial zones contributed in the colonization of Europe (Magri et al. 2006; Magri 2008). Modern populations with their diversity strongly shaped by the multiple glacial and interglacial cycles are likely descendants of the once existing extra-Mediterranean refugial populations, originating from Central Europe and extending toward the North (Magri et al. 2006).

Several studies on regional levels have evaluated the local patterns of genetic diversity (Ballian et al. 2012; Leonardi and Menozzi 1996; Gömöry et al.1999; Cvrčková et al. 2017). Analysing fine-scale spatial distribution of different genotypes in an isolated beech population in Saxony, Vornam et al. (2004) found a clumped spatial pattern of the genotypes within the stand, up to $30 \mathrm{~m}$ distance. This family structure of closely related nearby individuals may be the result of limited or oriented gene-flow (dominant wind direction) or may be due to preferential mating among nearby individuals, if selection by inbreeding depression has not occurred. Hence, local aspects are able to shape the demographic history of populations. More than that, it has been presumed that human activity linked to forest management has an impact on the distribution of the genetic diversity in populations. However, with pairwise comparisons among stands differing in management, Buiteveld et al. (2007) could not detect clear effects of management (shelterwood system) on the genetic constitution (e.g., allelic richness, rare alleles) of beech populations.

Developing CSF indicators, especially at the local level, requires collection of data from long-term plots as well as from newly established plots, to evaluate the genetic attributes at both the stand and landscape level (Bowditch et al. 2020). Among other indicators, the genetic characteristics of populations will enable the analyses of trends in CSF and allow the identification of priority areas for adaptation and mitigation. In a similar way, the overall evaluation of the standing genetic diversity provides a tool to monitor forest environmental services.

This study is a report on the molecular genetic variation of beech stands from the established study plots within the COST CLIMO project (Pretzsch et al. 2021) with the aim to characterize the standing genetic diversity within the plots and provide empirical genetic data for assessing CSF indicators in mountain forest ecosystems. Nuclear microsatellites used in previous studies were screened to characterize the genetic diversity and aspects of the regional distribution of the genetic variation in relation to local environmental conditions.

\section{Materials and methods}

\subsection{Study sites}

The 12 study sites included unthinned or slightly thinned pure beech forest stands distributed across Europe, and they were located in mountain regions with elevations varying from 551 to $1365 \mathrm{~m}$ a.s.1., except for one Bosnian site (BO2), where stand elevation was $147 \mathrm{~m}$ a.s.l. Established in the frame of the CLIMO project (empirical study, working group 2), 11 study plots larger than 0.1 ha with at least 50 trees were selected for the genetic analysis (Fig. 1; Table 1). Plant material was collected from 20 to 23 mature, mostly dominant beech trees. Individuals of one more beech stand were also sampled from northern Bosnia (BO2), which was not part of the CLIMO empirical study but exhibited the same plot characteristics. 
Fig. 1. Location of the study sites indicating within-stand genetic diversity $\left(H_{\mathrm{E}} / \mathrm{H}_{\mathrm{O}}\right)$, with the distribution of European beech (source: Euforgen, www.euforgen.org) in Europe in green. Expected $\left(H_{E}\right.$, red) and observed $\left(H_{O}\right.$, blue) heterozygosity values (derived from GenAlEx version 6.5) are illustrated with red and blue bar charts. [Colour online.]

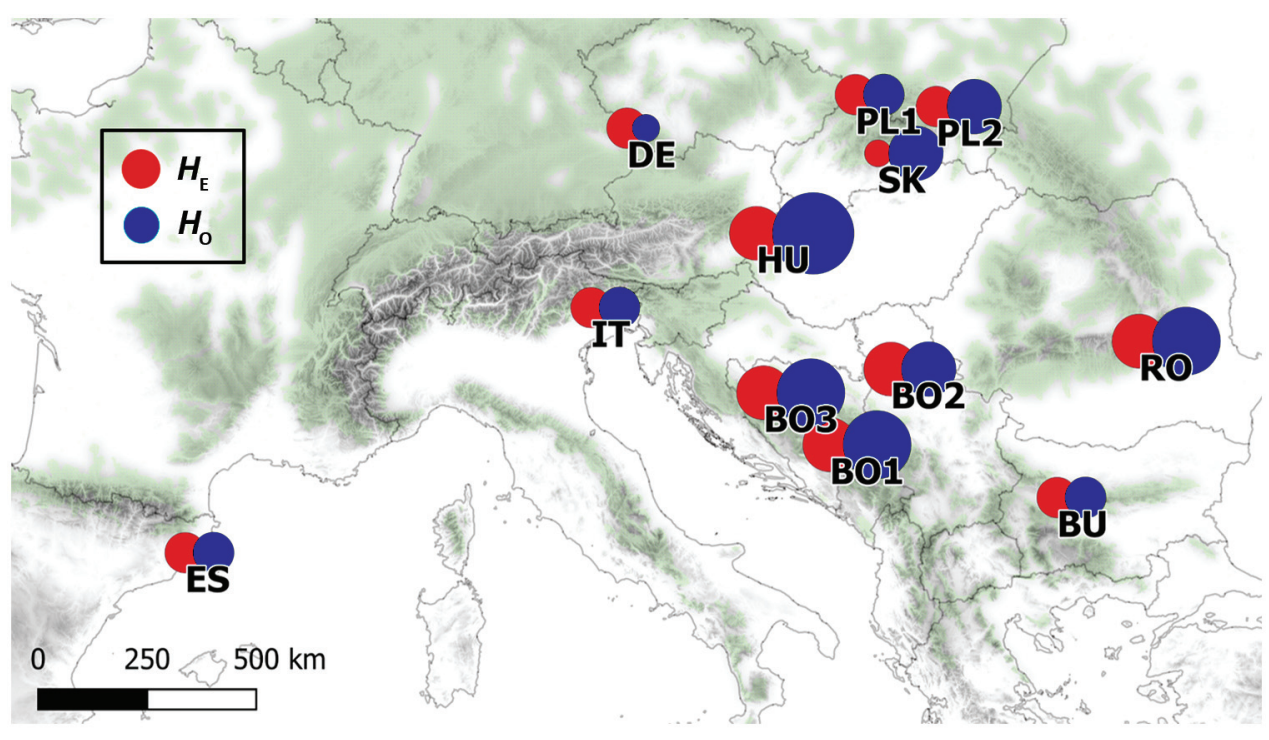

Table 1. Study sites and sampling design.

\begin{tabular}{|c|c|c|c|c|c|}
\hline ID & Country & Latitude & Longitude & $\begin{array}{l}\text { Elevation } \\
\text { (m a.s.1.) }\end{array}$ & $\begin{array}{l}\text { No. of } \\
\text { samples }\end{array}$ \\
\hline ES & Spain & 41.775 & 2.457222 & 1183 & 21 \\
\hline IT & Italy & 46.11133 & 12.42450 & 1083 & 20 \\
\hline $\mathrm{DE}$ & Germany & 49.085661 & 13.306530 & 1120 & 21 \\
\hline PL1 & Poland & 49.62243 & 18.91460 & 673 & 23 \\
\hline PL2 & Poland & 49.43298 & 20.90310 & 885 & 21 \\
\hline SK & Slovakia & 48.67797 & 19.47017 & 1055 & 20 \\
\hline $\mathrm{HU}$ & Hungary & 47.36286 & 16.48672 & 640 & 20 \\
\hline RO & Romania & 45.53662 & 25.88083 & 1339 & 20 \\
\hline BO1 & Bosnia and Herzegovina & 43.72444 & 18.28583 & 1352 & 20 \\
\hline $\mathrm{BO} 2$ & Bosnia and Herzegovina & 45.05333 & 19.78500 & 147 & 20 \\
\hline BO3 & Bosnia and Herzegovina & 44.64165 & 16.66000 & 551 & 20 \\
\hline BU & Bulgaria & 42.77917 & 23.881111 & 937 & 20 \\
\hline
\end{tabular}

\subsection{DNA isolation and microsatellite genotyping}

Total genomic DNA was isolated from silica-dried needles or cores from 246 F. sylvatica samples, 20 to 23 individuals per stand. DNA was extracted using the E.Z.N.A. ${ }^{\circledR}$ SP Plant DNA kit (Omega Bio-tek, Inc., Norcross, GA, USA) following the manufacturer's recommendations. Six nuclear microsatellite markers (nSSR), highly polymorphic in previous studies and providing the expected product sizes (Nonic et al. 2015; Cvrčková et al. 2017), were employed to identify genotypes for the following loci: FS1_15 (Pastorelli et al. 2003), csolfagus19, csolfagus31 (Lefevre et al. 2012), mfc5 (Tanaka et al. 1999), sfc0036 (Asuka et al. 2004), and DE576_A_0 (Lefevre et al. 2012). The nSSR regions were amplified in two multiplex (FS1_15+csolfagus149+csolfagus31 and mfc5+scf003+DE576_A_0) PCR reactions. We performed $11 \mu \mathrm{L}$ PCR reactions with $1 \mu \mathrm{L}$ of genomic DNA, 3.9 $\mu \mathrm{L}$ of Milli-Q ultrapure water (Merck Millipore, Billerica, MA, USA), $2.2 \mu \mathrm{L}$ of $(10 \times)$ DreamTaq Green PCR buffer (ThermoFisher, Waltham, MA, USA), $0.3 \mu \mathrm{L}$ of $\left(10 \mathrm{mmol} \cdot \mathrm{L}^{-1}\right) \mathrm{dNTP}$ mix (ThermoFisher, Waltham, MA, USA), $0.1 \mu \mathrm{L}$ of $\left(2.5 \mathrm{mmol} \cdot \mathrm{L}^{-1}\right)$ $\mathrm{MgCl}_{2}, 0.5-0.5 \mu \mathrm{L}\left(10 \mathrm{mmol} \cdot \mathrm{L}^{-1}\right)$ of each primer, and $0.1 \mu \mathrm{L}$ of DreamTaq Green DNA polymerase (ThermoFisher, Waltham,
MA, USA). Thermocycling conditions were as follows: $3 \mathrm{~min}$ at $94^{\circ} \mathrm{C}$, followed by nine cycles $\left(50 \mathrm{~s}\right.$ at $94^{\circ} \mathrm{C}, 1 \mathrm{~min}$ at $\left.70^{\circ} \mathrm{C}\right)$ and 34 cycles $\left(50 \mathrm{~s}\right.$ at $55^{\circ} \mathrm{C}, 2 \mathrm{~min}$ at $\left.70^{\circ} \mathrm{C}\right)$. Amplifications were performed with an Aeris ${ }^{\mathrm{TM}}$ Thermal Cycler (Esco Micro Pte. Ltd., Singapore). Microsatellite fragments were separated in a CEQ8000 (Beckman-Coulter, Brea, CA, USA) genetic analyser, and genotype scores were obtained with the pertaining software and by manual inspection.

\subsection{Environmental variables}

We selected three climatic variables (i.e., frequency of frost days per year — frs (days); monthly average precipitation — pre $(\mathrm{mm})$; monthly average daily mean temperature $-\operatorname{tmn}\left({ }^{\circ} \mathrm{C}\right)$ ) from the CRU TS version 4.03. database, available at high spatial resolution $(0.5 \times 0.5$ degree $)$ grids (Harris et al. 2014).

We retrieved data from 1901 to 2000 , which were then averaged over the periods separately for spring (frs_sp, pre_sp, tmn_sp), summer (frs_s, pre_s, tmn_s), autumn (frs_a, pre_a, tmn_a), and winter (frs_w, pre_w, tmn_w). In this way, we obtained 12 explanatory environmental variables. 


\subsection{Data analysis}

\section{Genetic diversity and differentiation}

We calculated standard diversity indexes $\left(N_{a}\right.$, number of alleles; $N_{\text {ae }}$, number of effective alleles; $H_{\mathrm{O}}$, observed heterozygosity; $H_{E}$, expected heterozygosity; $F_{I S}$, fixation index), Shannon's information index $(I)$, and the number of private alleles $\left(P_{\mathrm{A}}\right)$ for each stand using GenAlEx version 6.5 (Peakall and Smouse 2012). Pairwise $F_{\mathrm{ST}}$ between each pair of stands was calculated with the $\mathrm{R}$ package hierfstat (Goudet 2005). To test for correlation between geographical and genetic distances, $\mathrm{F}_{\mathrm{ST}}$ values and geographical distance matrices were compared with a Mantel test (Mantel 1967) based on 10000 permutations with the $R$ package ade 4 (Chessel 2004). Observed and expected heterozygosity were compared by a paired Student's $t$ test.

\section{Genetic structure}

Interpopulation structure among the 12 sites was investigated using Bayesian clustering both with STRUCTURE version 2.3.4. (Pritchard et al. 2000) and TESS version 2.3 (Chen et al. 2007), by testing 10 independent runs for a given number of inferred clusters $K$, from $K=2$ to 12 . TESS was run with a burn-in of 10000 and run length of 50000 iterations, while STRUCTURE runs consisted of 500000 MCMC generations, after a burn-in period of 100000 iterations with LOCPRIOR model described by Hubisz et al. (2009). Admixture model and uncorrelated allele frequencies model were used. STRUCTURE HARVESTER (Earl and von Holdt 2012) was used to apply the Evanno method (Evanno et al. 2005) to detect the value of $K$ that best fit the data in case of STRUCTURE runs. To determine the $K$ with the best fit for TESS results, average Deviation Information Criterion (DIC) values were plotted against $K$. The 10 runs of the best $K$ were averaged and visualized with the web application Pophelper (Francis 2017).

\section{Effects of environment on diversity}

We tested the effect of climatic variables and elevation on diversity indices with linear regression models. Prior to analyses, to simplify the model construction and account for collinearity among the variables, we reduced the number of climatic variables by means of principal component analyses (PCA), performed with the $\mathrm{R}$ package stats. Continuous variables were standardized (centred and scaled) using the scale function. PCA components were further used to build a linear regression model. Applying the step function, a standard stepwise selection method searching the minimum Akaike's information criterion was used to select the variables or factors in the final (best-fit) model. Final models were fitted using the $\mathrm{lm}$ function. Analyses were performed with the R package stats.

\section{Results}

\subsection{Genetic diversity and differentiation}

A total of 92 alleles were detected across the six nSSR loci examined, ranging from nine in DE576_A_0 to 28 in mfc5. Mean number of private alleles was greatest $(0.83)$ in $\mathrm{HU}$ and $\mathrm{BO} 1$ and zero in PL2 (Table 2). All microsatellite regions were polymorphic; as an extreme example, more than $50 \%$ of the examined individuals (11 out of 20) in the RO plot exhibited heterozygosity at each microsatellite loci. Similarly, except for six individuals, all BO3 trees were heterozygous at five or at all six loci (supplementary Fig. $S 1^{2}$ ). Genetic diversity was high along the plots, observed heterozygosity ranged from 0.69 to 0.93 while expected heterozygosity ranged from 0.74 to 0.81 . Shannon's information criterion ranged from 1.63 to 1.89. Most of the populations exhibited excess of heterozygotes (paired Student's $t$ test: $t_{[11]}=2.37, p=0.01$ ), and HU showed the highest heterozygosity excess based on the ratio
Table 2. Averaged genetic diversity parameters for nuclear microsatellite markers (nSSRs) in the studied Fagus sylvatica stands.

\begin{tabular}{lllllllr}
\hline ID & $N_{\mathrm{a}}$ & $N_{\mathrm{ae}}$ & $H_{\mathrm{O}}$ & $H_{\mathrm{E}}$ & \multicolumn{1}{l}{$P_{\mathrm{A}}$} & \multicolumn{1}{l}{$\mathrm{F}_{\mathrm{IS}}$} \\
\hline ES & 8.00 & 4.32 & 0.76 & 0.76 & 1.70 & 0.33 & -0.001 \\
IT & 7.50 & 4.30 & 0.78 & 0.76 & 1.63 & 0.17 & -0.023 \\
DE & 8.00 & 4.32 & 0.69 & 0.75 & 1.63 & 0.17 & 0.066 \\
PL1 & 8.00 & 5.08 & 0.78 & 0.77 & 1.73 & 0.17 & -0.002 \\
PL2 & 8.33 & 5.05 & 0.80 & 0.76 & 1.72 & 0.00 & -0.039 \\
SK & 7.67 & 4.30 & 0.80 & 0.74 & 1.64 & 0.33 & -0.079 \\
HU & 9.33 & 4.92 & 0.93 & 0.79 & 1.84 & 0.83 & -0.174 \\
RO & 8.67 & 5.44 & 0.87 & 0.79 & 1.82 & 0.17 & -0.109 \\
BO1 & 9.00 & 5.52 & 0.86 & 0.80 & 1.85 & 0.83 & -0.083 \\
BO2 & 9.50 & 5.64 & 0.83 & 0.79 & 1.89 & 0.33 & -0.049 \\
BO3 & 9.17 & 5.84 & 0.83 & 0.81 & 1.88 & 0.33 & -0.034 \\
BU & 8.67 & 4.66 & 0.76 & 0.76 & 1.74 & 0.50 & 0.011
\end{tabular}

Note: $N_{\mathrm{a}}$, number of alleles; $N_{\mathrm{ae}}$, number of effective alleles; $H_{\mathrm{O}}$, observed heterozygosity; $H_{\mathrm{E}}$, expected heterozygosity; $I$, Shannon's information index; $P_{\mathrm{A}}$, number of private alleles; $F_{\mathrm{IS}}$, fixation index); ES, Spain; IT, Italy; DE, Germany; PL1 and PL2, Poland; SK, Slovakia; HU, Hungary; RO, Romania; BO1, BO2, and BO3, Bosnia and Herzegovina; BU, Bulgaria.

of $H_{\mathrm{O}}$ and $H_{\mathrm{E}}$. There were no signs of inbreeding $\left(\mathrm{F}_{\mathrm{IS}}=-0.083\right.$ to 0.066).

Pairwise $F_{\text {ST }}$ values between stands ranged from 0.017 to 0.067 (supplementary Table $\left.S 1^{2}\right)$ and a significant Mantel test $(r=0.81$, $p<0.001$ ) between $F_{\mathrm{ST}}$ and geographic distances indicated that genetic differentiation among populations increases significantly with the geographical distance among sites, pronouncedly for sites at a distance higher than $750 \mathrm{~km}$ (Fig. 2).

\section{Population genetic structure}

STRUCTURE analysis on the microsatellite dataset revealed the highest $\Delta K$ for $K=5$ ( $\Delta K=3.35$; Fig. 3). Admixed individuals among clusters were observed. Both STRUCTURE and TESS analyses clearly discriminated the Spanish (ES) and the Bulgarian (BU) populations and classified those into individual clusters. The remnant three clusters differed slightly based on the two methods. The Italian (IT), German (DE), and one population from Poland (PL1) were clustered together. The other Polish population (PL2) clustered with the Slovakian population (SK). Based on TESS the Bosnian (BO1-BO3) and the Romanian (RO) populations formed a cluster, while based on STRUCTURE, the BO2 population was less clearly included in the same cluster. The Hungarian population was the most admixed; based on TESS, it resembled the Polish and Slovak populations.

\section{Effects of the environment on genetic diversity}

The first PCA axis (PC1.clim) of the 12 environmental variables explained $71 \%$ of the total variation among the studied populations and was dominated by the mean temperature (with negative sign) and the frost day frequency (with positive sign) in spring, summer, and autumn (supplementary Fig. S2 ${ }^{2}$ ) with loadings absolute values above 0.29 . The second PCA axis (PC2.clim) explained $20 \%$ of the remaining variation with precipitation in winter $(\leq 0.5)$ and spring and autumn $(\leq 0.4)$. Winter temperature $(\leq 0.3)$ and frost day frequency in winter $(>0.3)$ had the highest absolute values of loadings on this axis.

Linear regression analyses between principal components of the climate variables and diversity parameters revealed correlation of the climate with the number of alleles $\left(N_{\mathrm{a}}\right)$ and Shannon's information criterion $(I)$. The best linear model (adjusted $R^{2}=$ $0.63, p=0.01$ ) associated $N_{\mathrm{a}}$ with PC1.clim with a negative significant effect (slope $=-0.19, t=-2.92, p=0.002$; Fig. 4), while the

\footnotetext{
${ }^{2}$ Supplementary data are available with the article at https://doi.org/10.1139/cjfr-2020-0413.
} 
Fig. 2. Relationship between pairwise $F_{\mathrm{ST}}$ and geographic distances $(r=0.81, p<0.001)$ for the 12 Fagus sylvatica populations.

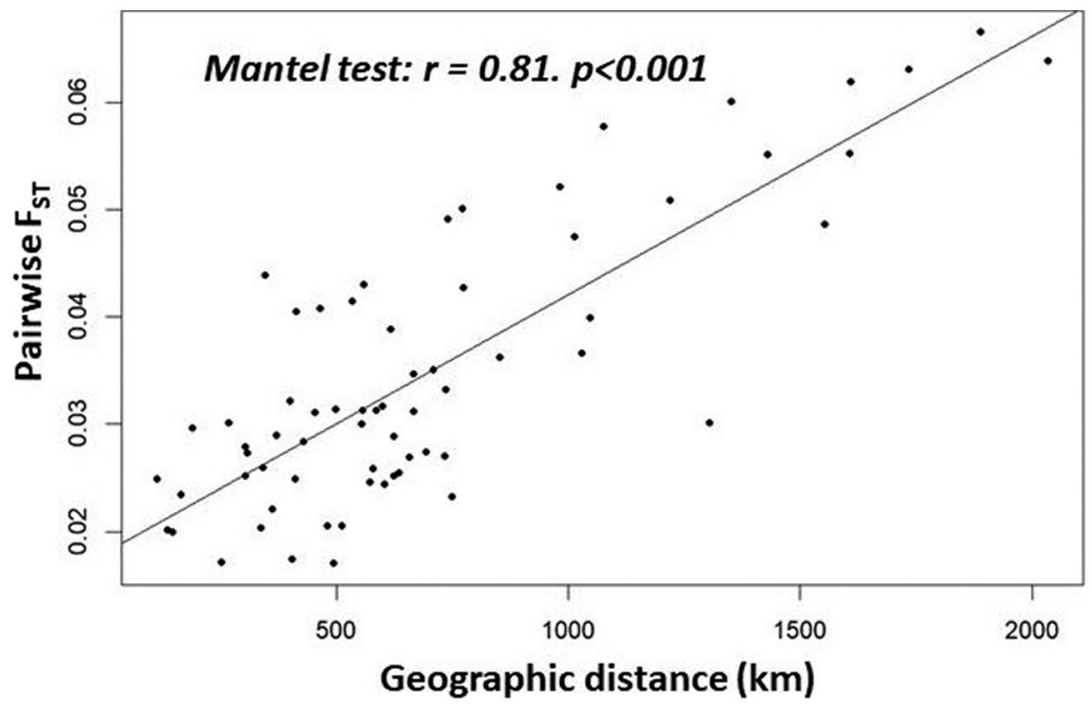

Fig. 3. Estimated genetic population structure of Fagus sylvatica stands based on nuclear microsatellite markers (nSSRs) for $K=5$ revealed by (A) STRUCTURE with the location priory model and (B) TESS. ES, Spain; IT, Italy; DE, Germany; PL1 and PL2, Poland; SK, Slovakia; HU, Hungary; RO, Romania; BO1, BO2, and BO3, Bosnia and Herzegovina; BU, Bulgaria. [Colour online.]
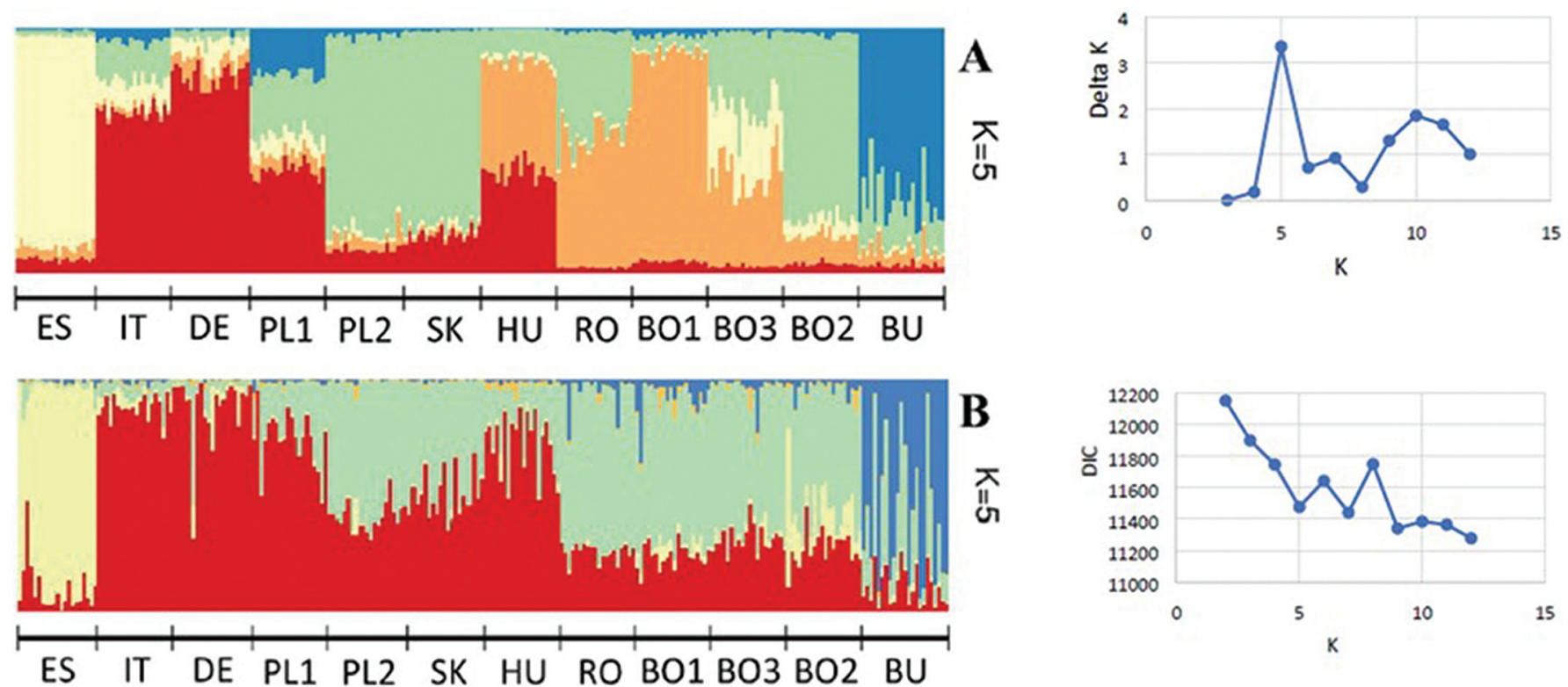

coefficients of the remaining PC3.clim, PC4.clim, and altitude were insignificant (supplementary Table $\mathrm{S}^{2}$ ). A significant linear model (adjusted $R^{2}=0.57, p=0.01$ ) also revealed the effect of climate on $I$. Both PC1.clim (slope $=-0.20, t=-3.15, p=0.01$ ) and PC3.clim (slope $=-0.78, t=-2.72, p=0.02$ ) had significant negative effects (supplementary Table $\mathrm{S2}^{2}$ ).

\section{Discussion}

High genome-level variability represents the key fitness component that helps populations to survive in different environments (Scott et al. 2020). Under climate change, when rapid shifts in environmental conditions take place, genetically more variable individuals are presumed to have more chances of survival and successful reproduction. The heterozygosity measure therefore is an important but easy to obtain indicator, predicting the survival potential of individuals and their populations specifically under severe conditions (Scott et al. 2020).

Continuously changing and newly developing markers and methods are applied for detecting population and individual genetic variation, among which highly variable microsatellite markers are still frequently used. Due to their high polymorphism, even a relatively low number of markers can screen the genome and characterize the genetic potential of populations (Allendorf et al. 2013). In this study, we analysed the standing genetic diversity of 12 European beech stands distributed across the species' distribution range. All beech stands of the established CLIMO study plots exhibited high levels of genetic variation based on the six nuclear DNA microsatellite markers. This is in line with former studies performed in natural beech populations, and it is attributed mostly to the high outcrossing rate 
Fig. 4. Regression of climate (PC1.clim) and genetic diversity indices $\left(N_{\mathrm{a}}\right.$, number of alleles; $I$, Shannon's information index) in the studied beech stands. ES (Spain), IT (Italy), DE (Germany), PL1, PL2 (Poland), SK (Slovakia), HU (Hungary), RO (Romania), BO1, BO2, BO3 (Bosnia and Herzegovina), BU (Bulgaria).
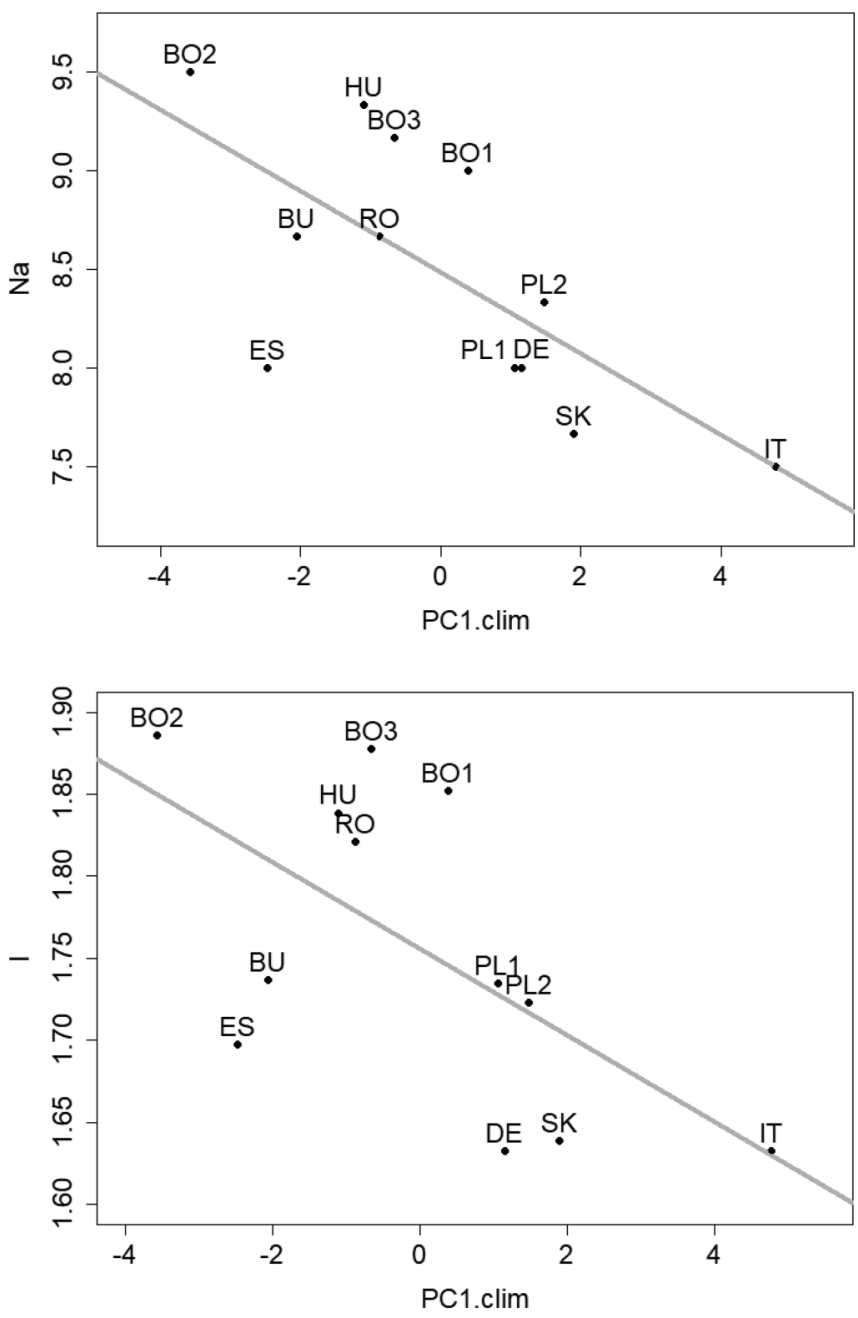

characteristic for most wind pollinated tree species (Petit and Hampe 2006). However, observed heterozygosity values detected in our study $\left(H_{\mathrm{O}}: 0.69-0.93\right)$ were higher compared with Czech populations ( $H_{\mathrm{O}}$ : 0.664-0.754; Cvrčková et al. 2017) and with other European populations ( $H_{\mathrm{O}}$ : 0.560-0.721; Buiteveld et al. 2007).

The highest diversity values were found at sites from the Balkan Peninsula, in Bosnia and the Southern Carpathians in Romania, where genetic hotspots and several possible glacial refugia were formerly reported (Gömöry et al. 2010). Moreover, the complex history of the Balkan Peninsula that remained moderately favourable for the survival of temperate forest trees in the past glacial period is expected to have promoted formation and long-term persistence of multiple genetic lineages that are reflected in high levels of allelic and haplotypic richness (Gömöry et al. 2020).

Despite the fact that in most studies, heterozygote deficiency was reported in beech forest populations (Vornam 2004; Buiteveld et al. 2007; Cvrčková et al. 2017), in our study, most of the stands showed an excess of heterozygotes with the highest $H_{O}$ value at the Hungarian site (Fig. 1; Table 2). Former studies have revealed that for mixed-mating forest tree species, seeds and younger stands often show an excess of homozygotes (Muona 1989), but with increasing age, this excess is selectively removed (Buiteveld et al.
2007). As in this study, only mature, old trees were sampled within the study plots, heterozygotes could be more frequent than expected because of this age effect. The highest observed heterozygosity was detected at the Hungarian site, where beech sustains at a low elevation (640 $\mathrm{m}$ a.s.1.) and the forest stand is close to the eastern xeric limit of the species. A fine-scale analysis showed that late spring and summer drought strongly affects the limits of beech distribution in the area (Czúcz et al. 2013). One can presume that abiotic stress acting as a selective force on the genome (massively) favours trees with overall high heterozygosity. Interestingly, a recent study in Swiss stone pine (Pinus cembra L.) found similar effects when comparing central and marginal stands (Dauphin et al. 2020). Even though the analysed genomic regions in our study are possibly selectively neutral, they may be associated with more adaptive sites, or adaptation may affect so many sites in the genome that many of those are linked to microsatellites. Given that similar findings hold also for isozymes, it may be assumed that trees with their long lifespan and sedentary lifestyle generally benefit from diversity (i.e., heterozygosity) throughout their genomes. This could simply be due to alleles (especially their promoters) acting differently to environmental cues and due to advantages of the combinations of expressed alleles in certain situations (Rodríguez-Quilón et al. 2015; Lindtke et al. 2012). On the other hand, it cannot be excluded that increased observed heterozygosity may result from forest management, as the highest and largest individuals were maintained in these plots. This would point into the same direction that more heterozygous trees are at an advantage regarding growth. However, in our study, tree height and trunk diameter (of the remaining and selected trees) were not significantly correlated with the observed heterozygosity of the individuals (data not shown), similar to previous investigations (Buiteveld et al. 2007).

Differentiation among study regions was generally weak; however, there was considerable within-region differentiation especially within the Balkan region. A Mantel test $(r=0.81, p<0.001)$ showed that genetic differentiation increased significantly with the geographical distance among sites, pronouncedly for sites at a distance higher than $750 \mathrm{~km}$. Bayesian clustering using STRUCTURE and TESS identified the most probable number $(K)$ of groups of populations to be $K=5$, showing a well-separated group south of the Pyrenees in Spain. This is in line with earlier findings based on cpDNA, reflecting a different gene pool for beech in Western Europe (Magri et al. 2006). Another well-separated group comprised all samples from the Bulgarian site, where a higher number of specific alleles was also detected. The distinct genetic pattern may indicate that the Bulgarian samples originate from a local relict population, or alternatively, they may have a special allele composition because of the stand characteristics and as a consequence of past historical events. Sampled trees are growing just below the tree line at high elevation (1365 $\mathrm{m}$ a.s.1.) and are very old (350 years of age). Forest cover in the past was low in this area due to widespread pastures. This type of land use has only declined during the last century, and since then forest cover regenerated naturally (T. Zlatanov, Bulgarian Academy of Sciences, personal communication). Moreover, the location is close to the distribution of the sister species, Fagus orientalis Lipsky, but no visible signs of hybridization or introgression were formerly reported from this area (Comps et al. 2001). However, gene flow has been previously detected between the two species in Bulgaria, using genetic markers (Paule 1995).

Further groups in the Bayesian clustering comprised the rest of the study sites slightly separating samples originating from Central Europe (Germany, northern Italy, and southwestern Poland) from those of the Southern Carpathians and the Balkans, supporting the theory of past multiple refugia and colonization routes reported in earlier studies (Magri 2008; Gömöry et al. 2020).

However, many recent studies have shifted their attention from describing genetic parameters towards genetic processes. Habitat 
quality variables, affected by long-term climatic trends, are expected to explain some genetic variation and may be the drivers of local population demography (Nicolé et al. 2011). In our study, regression analysis on climate variables showed significant correlation with the number of alleles and Shannon's information index. Higher average temperature and fewer frost days were associated with higher number of alleles and higher Shannon's index. Whether this correlation simply reflects the closeness to southern ice age refugia or has some other reason, would require further study.

In conclusion, our study reflects local aspects of the standing genetic diversity in 12 pure CLIMO beech stands along the distribution range of the species. High genetic diversity revealed at these empirical study sites is in accordance with former studies performed on beech populations and reflects the natural character of the studied beech forests where the plots have been established. Besides the overall high level of genetic variation within stands, we also found genetically diverging sites reflecting local stand growth characteristics. The genetic parameters of each stand could be assessed as a resource for CSF indicators, interpreted especially at the local level. We stress the important role of high heterozygosity in response to varying or fluctuating climate conditions; highly heterozygous trees may be more "climate smart" (i.e., in a better position in a changing climate) than others. A high level of standing genetic diversity preserved in populations should be considered indeed a precondition for good performance. Genetic parameters should therefore be taken into account when comparing growth and yield patterns for forest tree populations.

\section{Acknowledgements}

The authors acknowledge the networking support by the COST (European Cooperation in Science and Technology) Action CLIMO (Climate-Smart Forestry in Mountain Regions - CA15226) financially supported by the EU Framework Programme for Research and Innovation HORIZON 2020. Michal Bosela was additionally supported by the Slovak Research and Development Agency (project Nos. APVV-15-0265 and APVV-19-0183).

\section{References}

Allendorf, F.W., Luikart, G., and Aitken, S. 2013. Conservation and the genetics of populations. 2nd ed. Wiley-Blackwell.

Asuka, Y., Tani, N., Tsumura, Y., and Tomaru, N. 2004. Development and characterization of microsatellite markers for Fagus crenata Blume. Mol. Ecol. Notes, 4: 101-103. doi:10.1046/j.1471-8286.2003.00583.x.

Ballian, D., Bogunić, F., Mujezinović, O., and Kajba, D. 2012. Genetic differentiation of European beech (Fagus sylvatica L.) in Bosnia and Herczegovina. Šumarski list, 136(11-12): 587-595. Available from https://hrcak.srce.hr/94591.

Barrett, R.H.D., and Schluter, D. 2008. Adaptation from standing genetic variation. Trends Ecol. Evol. 23(1): 38-44. doi:10.1016/j.tree.2007.09.008. PMID: 18006185.

Belletti, P., and Lanteri, S. 1996. Allozyme variation among European beech (Fagus sylvatica L.) stands in Piedmont, north-western Italy. Silvae Genet. 45(1): 33-37. Available from https://www.thuenen.de/media/institute/fg/ PDF/Silvae_Genetica/1996/Vol._45_Heft_1/45_1_33.pdf.

Bowditch, E., Santopuoli, G., Binder, F., del Río, M., La Porta, N., Kluvankova, T., et al. 2020. What is Climate-Smart Forestry? A definition from a multinational collaborative process focused on mountain regions of Europe. Ecosyst. Serv. 43: 101113. doi:10.1016/j.ecoser.2020.101113.

Buiteveld, J., Vendramin, G.G., Leonardi, S., Kamer, K., and Geburek, T. 2007. Genetic diversity and differentiation in European beech (Fagus sylvatica L.) stands varying in management history. For. Ecol. Manage. 247: 98-106. doi:10.1016/j.foreco.2007.04.018.

Chen, C., Durand, E., Forbes, F., and Francois, O. 2007. Bayesian clustering algorithms ascertaining spatial population structure: a new computer program and a comparison study. Mol. Ecol. Notes, 7: 747-756. doi:10.1111/ j.1471-8286.2007.01769.x.

Chessel, D., Dufour, A.B., and Thioulouse, J. 2004. The ade4 package-I-Onetable methods. R News, 4(1): 5-10. Available from http://thioulouse.fr/ref/ ade4-Rnews.pdf.

Comps, B., Gömöry, D., Letouzey, J., Thiebaut, B., and Petit, R.J. 2001. Diverging trends between heterozygosity and allelic richness during postglacial colonization in the European beech. Genetics, 157: 389-397. PMID:11139519.

Cvrčková, H., Máchová, P., Poláková, L., and Trčková, O. 2017. Evaluation of the genetic diversity of selected Fagus sylvatica L. populations in the Czech
Republic using nuclear microsatellites. J. For. Sci. 63(2): 53-61. doi:10.17221/ 88/2016-JFS.

Czúcz, B., Gálhidy, L., and Mátyás, C. 2013. Present and forecasted distribution of beech and sessile oak at the xeric climatic limits in Central Europe. Bull. For. Sci. 3(1): 39-53. [In Hungarian.]

Dauphin, B., Wüest, R.O., Brodbeck, S., Zoller, S., Fischer, M.C., Holderegger, R., et al. 2020. Disentangling the effects of geographic peripherality and habitat suitability on neutral and adaptive genetic variation in Swiss stone pine. Mol. Ecol. 29(11): 1972 -1989. doi:10.1111/mec.15467. PMID:32395881.

De Carvalho, D., Ingvarsson, P.K., Joseph, J., Suter, L., Sedivy, C., Macaya-Sanz, D., et al. 2010. Admixture facilitates adaptation from standing variation in the European aspen (Populus tremula L.), a widespread forest tree. Mol. Ecol. 19: 1638-1650. doi:10.1111/j.1365-294X.2010.04595.x. PMID:20345678.

Demesure, B., Comps, B., and Petit, R.J. 1996. Chloroplast DNA phylogeography of the Common Beech (Fagus sylvatica L.) in Europe. Evolution, 50(6): 2515-2520. doi:10.2307/2410719. PMID:28565658.

Earl, D.A., and von Holdt, B.M. 2012. STRUCTURE HARVESTER: a website and program for visualizing STRUCTURE output and implementing the Evanno method. Conserv. Genet. Resour. 4(2): 359-361. doi:10.1007/s12686011-9548-7.

Evanno, G., Regnaut, S., and Goudet, J. 2005. Detecting the number of clusters of individuals using the software STRUCTURE: a simulation study. Mol. Ecol. 14(8): 2611-2620. doi:10.1111/j.1365-294X.2005.02553.x. PMID:15969739.

Francis, R.M. 2017. Pophelper: an R package and web app to analyse and visualize population structure. Mol. Ecol. Resour. 17(1): 27-32. doi:10.1111/ 1755-0998.12509. PMID:26850166.

Goudet, J. 2005. Hierfstat, a package for R to compute and test hierarchical F-statistics. Mol. Ecol. Notes, 5(1): 184-186. doi:10.1111/j.1471-8286.2004.00828.x.

Gömöry, D., Paule, L., Brus, R., Zhelev, P., Tomovic, Z., and Gračan, J. 1999. Genetic differentiation and phylogeny of beech on the Balkan Peninsula. J. Evol. Biol. 12(4): 746-754. doi:10.1046/j.1420-9101.1999.00076.x.

Gömöry, D., Paule, L., Shvadchak, I.M., Popescu, F., Sulkowska, F.M., Hynek, V., and Longauer, R. 2003. Spatial patterns of the genetic differentiation in European Beech (Fagus sylvatica L.) at allozyme loci in the Carpathians and the adjacent regions. Silvae Genet. 52(2): 78-83. Available from https://www.thuenen.de/de/infothek/publikationen/silvae-genetica/archiv/.

Gömöry, D., Longauer, R., Paule, L., Krajmerová, D., and Schmidtová, J. 2010. Across-species patterns of genetic variation in forest trees of Central Europe. Biodivers. Conserv. 19: 2025-2038. doi:10.1007/s10531-010-9823-z.

Gömöry, D., Zhelev, P., and Brus, R. 2020. The Balkans: a genetic hotspot but not a universal colonization source for trees. Plant Syst. Evol. 306: 5. doi:10.1007/s00606-020-01647-X

Harris, R.M.B., Grose, M.R., Lee, G., Bindoff, N.L., Porfirio, L.L., and Fox-Hughes, P. 2014. Climate projections for ecologists. WIREs Clim. Change, 5: 621-637. doi:10.1002/wcc.291.

Hewitt, G.M. 2004. Genetic consequences of climatic oscillations in the Quaternary. Philos. Trans. R Soc. B Biol. Sci. 359: 183-195. doi:10.1098/rstb.2003.1388. PMID:15101575.

Hubisz, M.J., Falush, D., Stephens, M., and Pritchard, J.K. 2009. Inferring weak population structure with the assistance of sample group information. Mol. Ecol. Resour. 9(5): 1322-1332. doi:10.1111/j.1755-0998.2009.02591.x. PMID:21564903.

Lefevre, S., Wagner, S., Petit, R.J., and De La Fontaine, G. 2012. Multiplexed microsatellite markers for genetic studies of beech. Mol. Ecol. Resour. 12: 484-491. doi:10.1111/j.1755-0998.2011.03094.x. PMID:22145937.

Leonardi, S., and Menozzi, P. 1996. Spatial structure of genetic variability in natural stands of Fagus sylvatica L. (beech) in Italy. Heredity, 77: 359-368. doi:10.1038/hdy.1996.154.

Lindtke, D., Buerkle, C.A., Barbará, T., Heinze, B., Castiglione, S., Bartha, D., and Lexer, C. 2012. Recombinant hybrids retain heterozygosity at many loci: new insights into the genomics of reproductive isolation in Populus. Mol. Ecol. 21(20): 5042-5058. doi:10.1111/j.1365-294X.2012.05744.x. PMID:22989336.

Magri, D. 2008. Patterns of post-glacial spread and the extent of glacial refugia of European beech (Fagus sylvatica). J. Biogeogr. 35: 450-463. doi:10.1111/j.13652699.2007.01803.x.

Magri, D., Vendramin, G.G., Comps, B., Dupanloup, I., Geburek, T., Gömöry, D., et al. 2006. A new scenario for the Quaternary history of European beech populations: palaeobotanic al evidence and genetic consequences. New Phytol. 171: 199-221. doi:10.1111/j.1469-8137.2006.01740.x. PMID:16771995.

Mantel, N. 1967. The detection of disease clustering and a generalized regression approach. Cancer Res. 27: 209-220. PMID:6018555.

Mátyás, C.S., and Kramer, K. 2016. Climate change affects forest genetic resources: consequences for adaptive management. FORGER Policy Brief 2016. doi:10.13140/RG.2.1.3485.8009.

Muona, O. 1989. Population genetics in forest tree improvement. In Plant population genetics, breeding and genetic resources. Edited by A.H.D. Brown, M.T. Cleggs, A.L. Kahler, and B.S. Weir. Sinauer Associates, Sunderland, Mass. pp. 287-298.

Nabuurs, G.J., Verkerk, P.J., Gonzaléz Olabarria, J.R., Trasobares, A., and Cienciala, E. 2018. Climate-smart forestry: mitigation, impact in three European regions. From Science to Policy 6. European Forest Institute. Available from https://efi.int/sites/default/files/files/publication-bank/2018/ efi_fstp_6_2018.pdf. 
Nicolé, F., Dahlgren, J.P., Vivat, A., Till-Bottraud, I., and Ehrlen, J. 2011. Interdependent effects of habitat quality and climate on population growth of an endangered plant. J. Ecol. 99(5): 1211-1218. doi:10.1111/j.1365-2745.2011.01852.x.

Nonic, M., Heinze, B., Mengl, M., Devetakovic, J., and Slunksky, R. 2015. Intra-population genetic diversity of beech in northern Serbia assessed by microsatellite markers. In Proceedings of the International conference, Reforestation challenges, 3-6 June 2015, Belgrade, Serbia. pp. 266-275. Available from https://www.reforestationchallenges.org/Conferences.htm

Paule, L. 1995. Gene conservation in European beech (Fagus sylvatica L.). For. Genet. 2(3): 161-170. Available from https://www.researchgate.net/profile/ Ladislav_Paule/publication/230554058_Gene_conservation_in_European_beech_ Fagus_sylvatica_L/links/Ofcfd50ddd0f002b03000000/Gene-conservation-inEuropean-beech-Fagus-sylvatica-L.pdf.

Pastorelli, R., Smulders, J.M.J., Van't Westende, W.P.C., Vosman, B. Giannini, R., Vettori, C., and Vendramin, G.G. 2003. Characterization of microsatellite markers in Fagus sylvatica L. and Fagus orientalis Lipsky. Mol. Ecol. Notes, 3(1): 76-78. doi:10.1046/j.1471-8286.2003.00355.x.

Peakall, P.E., and Smouse, R. 2012. GenAlEx 6.5: genetic analysis in Excel. Population genetic software for teaching and research - an update. Bioinformatics, 28(19): 2537-2539. doi:10.1093/bioinformatics/bts460. PMID: 22820204.

Petit, R.J., and Hampe, A. 2006. Some evolutionary consequences of being a tree. Annu. Rev. Ecol. Evol. Syst. 37: 187-214. doi:10.1146/annurev.ecolsys.37. 091305.110215.
Pretzsch, H., Hilmers, T., Uhl, E., Bielak, K., Bosela, M., del Rio, M., et al. 2021. European beech (Fagus sylvatica L.) grows better in mixed than in mono-specific stands at the edge of its distribution in mountain forests. Eur. J. For. Res. 140: 127-145. doi:10.1007/s10342-020-01319-y.

Pritchard, J.K., Stephens, M., and Donnelly, P. 2000. Inference of population structure using multilocus genotype data. Genetics, 155(2): 945-959. PMID:10835412.

Rodríguez-Quilón, I., Santos-del-Blanco, L., Grivet, D., Jaramillo-Correa, J.P., Majada, J., Vendramin, G.G., et al. 2015. Local effects drive heterozygosityfitness correlations in an outcrossing long-lived tree. Proc. R. Soc. B Biol. Sci. 282(1820): 20152230. doi:10.1098/rspb.2015.2230. PMID:26631567.

Scott, P.A., Allison, L.J., Field, K.J., Averill-Murray, R.C., and Shaffer, H.B. 2020. Individual heterozygosity predicts translocation success in threatened desert tortoises. Science, 370(6520): 1086-1089. doi:10.1126/science. abb0421. PMID:33243888.

Tanaka, K., Tsumura, Y., and Nakamura, T. 1999. Development and polymorphism of microsatellite markers for Fagus crenata and the closely related species, F. japonica. Theor. Appl. Genet. 99: 11-15. doi:10.1007/s001220051203.

Vornam, B., Decarli, N., and Gailing, O. 2004. Spatial distribution of genetic variation in a natural beech stand (Fagus sylvatica L.) based on microsatellite markers. Conserv. Genet. 5: 561-570. doi:10.1023/B:COGE.0000041025.82917. ac. 